\title{
Polymorphisms in VEGF and $K D R$ genes in the development of endometriosis: a systematic review
}

\author{
Jessica Vilarinho Cardoso 1 \\ Daniel Escorsim Machado 2 \\ Renato Ferrari 3 \\ Mayara Calixto da Silva 4 \\ Plínio Tostes Berardo 5 \\ Jamila Alessandra Perini 6
}

\footnotetext{
1 Programa de Pós-Graduação em Saúde Pública e Meio Ambiente. Escola Nacional de Saúde Pública. Fundação Osvaldo Cruz. Rio de Janeiro, RJ, Brasil.

2,4,6 Laboratório de Pesquisa de Ciências Farmacêuticas. Unidade de Farmácia. Centro Universitário Estadual da Zona Oeste. Av. Manoel Caldeira de Alvarenga, 1203. Campo Grande. Rio de Janeiro, RJ, Brasil. CEP: 23.070-200. E-mail: jamilaperini@yahoo.com.br

3 Serviço de Ginecologia. Hospital Moncorvo Filho. Rio de Janeiro, RJ, Brasil.

5 Serviço de Ginecologia. Hospital Federal dos Servidores do Estado. Rio de Janeiro, RJ, Brasil.
}

\begin{abstract}
Objectives: to review studies that used case-control design to verify the association of polymorphisms in VEGF and KDR genes in the development of endometriosis.

Methods: the systematic review selected articles published until September 1, 2015 from PubMed, MEDLINE, BVS, SciELO databases, considering the following key words: endometriosis and ("polymorphism" or "SNP" or "genetic polymorphism") and ("VEGF" OR "Vascular endothelial growth factor" or "VEGFR-2" or "Vascular endothelial growth factor2" or "KDR" or "Kinase Insert Domain Receptor").

Results: 106 articles were identified, only 11 were eligible. Discrepant results were observed regarding polymorphisms in VEGF gene in the development of endometriosis, which can be explained by methodological differences, sample size, eligible control type, using the unadjusted risk estimates and the heterogeneity of the studied population. Only one study investigated polymorphisms in KDR gene in the development of endometriosis, however it was ineligible for this review.

Conclusions: to avoid discrepancy in the results, we suggest that the ideal control group should be formed by fertile women and free of gynecological diseases. Multicentric studies with adequate design, involving different population besides the combined analysis on polymorphisms in VEGF and KDR genes are still necessary to contribute in the understanding of this disease, which are social, clinical and economical problems.
\end{abstract}

Key words Endometriosis, VEGF, KDR, Polymorphism, Infertility 


\section{Introduction}

Endometriosis is a gynecological disease characterized by the presence of functional endometrial tissue outside the uterine cavity, representing one of the most common gynecological disorders. ${ }^{1}$ The real profile of patients with endometriosis is uncertain, although there is a consensus that it is present in at least $10 \%$ of the women at reproductive age, $, 2,330$ to $50 \%$ of infertile women 4 and 3 to $5 \%$ of postmenopausal women. 5

Women with endometriosis may be asymptomatic $(10.7 \%)$, however, most of them present symptoms in different intensities, the main ones are: dysmenorrhoea (52-97\%), chronic pelvic pain (22$69 \%$ ), infertility (25-59\%), dyspareunia (44-71\%) and intestinal symptoms (71\%) and cyclic urinary (60\%).6-8 Endometriosis causes physical, mental and social consequences to women, bearing in mind that their psyche, interpersonal and martial relationships are affected by the problems of the symptoms, in particularly, by the difficulty of bearing children. 9

There are several theories explaining about the appearance of endometriosis; however its etiology is still not clear. The most widely accepted theory until today is Sampson's proposal, 10 who described that the endometrial tissue, by backward menstrual flow, returns to the uterine tubes and adheres to the peritoneal cavity. For this to occur, the angiogenesis process is essential and it is characterized by the growth of new blood vessels from pre-existing ones.11 Among the pro-angiogenic factors, the vascular endothelial growth factor $(V E G F)$ is highlighted and plays an important role in the development of endometriosis. 11 In 2008, our group observed an increased distribution of $V E G F$ and its receptor $V E G F R-2$ in samples of endometriosis of the ovary, bladder and the recto-sigmoid, when it was compared to control and the largest distribution of VEGF and VEGFR-2 was observed in the endometriosis of the recto-sigmoid,which is the most severe. 12

$V E G F$ is encoded by a gene with the same name, located on chromosome $6 \mathrm{p} 21.3$, composed by eight exons, 13 while its receptor $V E G F R-2$ is encoded by $K D R$ gene (kinase insert domain receptor), located on chromosome 4q11-q12, composed by 30 exons. ${ }^{14}$ Both genes are polymorphic, highlighting in the study on endometriosis, five single nucleotide polymorphisms (SNPs) in VEGF gene (rs699947, rs833061, rs1570360, rs2010963 and rs3025039) and three in $K D R$ gene (rs1870377, rs2305948 and rs2071559), due to the high frequency which occurs in different populations, although interfering signifi- cantly in the activity or in the enzyme expression. ${ }^{15-}$ 18

Recently, our group observed a positive association for $V E G F$ rs $1570360 \mathrm{SNP}$ in the development of endometriosis (OR: 1.90; CI95\%: 1.23-2.97) in Brazilian women. ${ }^{8}$ Several case-control studies also investigated the influence of SNPs in $V E G F$ or $K D R$ genes in the development of endometriosis. $8,17,19-37$ However, the results of the analysis are still controversial. In this context, the aim of this study was to review all the studies that used case-control design to investigate the magnitude of SNPs association of $V E G F$ and/or KDR genes susceptibility to develop endometriosis, in order to discuss the possible causes of the conflicting results already described.

\section{Methods}

To identify all the studies published until September 1, 2015 on the associations among SNPs of VEGF and/or $K D R$ and the development of endometriosis, an evaluation on titles and abstracts of the studies was performed by two researchers in an independent form and "blinded" in PubMed, Medline, BVS and SciELO databases using the following keywords: ("endometriosis") AND ("polymorphism" OR "SNP" $O R$ "genetic polymorphism" $O R$ "genetic polymorphisms") $A N D$ ("VEGF" OR "Vascular endothelial growth factor" $O R$ "VEGFR-2" $O R$ "Vascular endothelial growth factor-2" $O R$ "Vascular endothelial growth factor-2" $O R$ "KDR" $O R$ "Kinase Insert Domain Receptor"). The studies were selected according to the inclusion and exclusion criteria, pre-selected and described as followed.

The inclusion criteria for this review were casecontrol design studies and that evaluated associations among polymorphisms of $V E G F$ and/or $K D R$ genes and the development of endometriosis. As for the period of the publication, articles that were published until September 2015 were included without any restriction of languages.

The exclusion criteria of the study were: (I) the absence of a control population; (II) incomplete data associations; (III) duplicated data; (IV) metaanalysis, review, letters, commentaries or editorial articles; (V) those that did not analyze SNPs in $V E G F$ and/or KDR; (VI) and did not include patients with endometriosis; (VII) those that did not have access to the complete text.

After performing a search strategy in PubMed, Medline, BVS and SciELO databases in articles which studied SNPs in VEGF and/or KDR genes with the development of endometriosis, the following information was extracted: the first author, 
publication year, journal; country where the study was conducted; number of cases and controls; mean age of cases and controls with their respective deviation standard and/or interval; selection on criteria/eligibility and exclusion of cases of endometriosis and controls; endometriosis staging; control source; type of SNP; genotyping technique used to identify the studied SNPs; data of allelic and genotypic frequency of the SNPs and statistic data of odds ratio (OR) with its respective $95 \%$ confidence intervals (CI95\%).

\section{Evaluation on quality in the included studies}

Two reviewers independently evaluated the methodological quality of 19 studies included in this review, using STROBE (Strengthening the Reporting of Observational Studies in Epidemiology), a criteria instrument. 38 Twenty and two evaluated items received a score from 0 to 1 . These items were related to the title and the abstract of the article (item 1), the introduction (items 2 and 3 ), the methods (items 4 to 12), the results (items 13 to 17 ), the discussion (items 18 to 21 ) and the financial information (item 22). After evaluating all the criteria, each article received a score from 0 to 22 of each researcher. The final score was performed an average of the two grades transformed into percentage to better evaluate the quality of the articles. Previously, the reviewers described if the articles reached a percentage higher than $50 \%$, they would be consi-dered satisfactory.

\section{Results}

Figure 1 shows a flowchart on the selection of articles for this review. The search strategy identified 100 publications on $V E G F$ gene and 6 publications on $K D R$, no articles were found evaluating simultaneously the influence of SNPs in both genes with the development of endometriosis. After removing the duplicated articles, 34 were selected for reading the titles and abstracts. However, 14 studies were excluded: 5 because they were meta-analyzes, 2 because they were reviews, one because it was a criticism on the meta-analysis published before, one because it explored SNPs in $I L-10$ gene instead of polymorphisms in $V E G F$ and/or $K D R$ genes, 4 because they studied patients with adenomyosis and one because it evaluated women with pterygium instead of patients with endometriosis. After the selection of the abstracts, a study was excluded because the text was not completely available. 19 After a thorough reading of 19 articles eligible for this review, the inclusion and exclusion criteria on cases and controls were evaluated and 8 studies were still excluded: 5 used endometriosis cases without histopathological confirmation of the disease;20,25,28,30,34 2 which included controls did not have surgery procedures (laparoscopy and/or laparotomy) in confirming the diagnosis of endometriosis;22,29 and 1 which included controls only performed an ultrasound and was diagnosed negative for the disease. 17 Thus, 11 case-control studies were included in this review that evaluated SNPs only in $V E G F$ gene susceptibility to develop endometriosis from 2005 to $2015.8,21,23,24,26,27,31$ $33,36,37$ In relation to evaluate the quality of 11 studies selected for this review, all the articles reached a percentage greater than $50 \% 38$ and the average score ranged between 12 to 21 points (55$96 \%$ ). The studies that had the lowest and the highest score, according to the STROBE criteria were Kim et al. 24 and Perini et al.,8 respectively (Table 1).

In this review 4205 women's data were included (2096 with endometriosis and 2109 controls) from Asian countries, 21,24,27,32 North America,33 North Africa, ${ }^{8}$ Europe, $23,26,37$ Euro-Asian countries ${ }^{31}$ and Africa. 36

Table 1 describes the inclusion and exclusion criteria of the group with endometriosis, emphasizing that all the studies considered the women eligible who had surgical diagnosis of the disease with histopathological confirmation. Whereas the staging of the disease was found in $4(36.3 \%)$ studies that included patients in stage I, II, III or IV;24,31,33,36 $3(27.3 \%)$ grouped into stages I-II or III-IV;8,23,26 2 (18.2\%) included only women in stages I and II;32,37 one $(9.1 \%)$ included patients in stage III and IV21 and another $(9.1 \%)$ showed no information on surgical staging of the disease. ${ }^{27}$ In relation to the exclusion criteria of the group with cases of endometriosis, $2(18.2 \%)$ studies did not inform any criteria, 27,33 while others, a total of $9(81.8 \%)$ considered patients who had a history of angiogenesis-dependent diseases or that it could be associated to polymorphisms of $V E G F$, and women who presented adenomyosis, a pelvic inflammatory disease, bilateral tubal occlusion and myoma.

For the control group (Table 2), all the studies included women with surgical diagnosis of endometriosis, although 3 (27.3\%) studies included women who underwent surgery for tubal ligation, $8,26,323$ (27.3\%) included women who underwent surgery to remove cyst in the ovary; $8,21,232$ $(18.2 \%)$ included women who underwent surgery to remove myoma; 8,232 (18.2\%) included women who underwent hysterectomy 21,27 and 6 (54.5\%) included 
Figure 1

Flowchart of the selected articles included in the review.

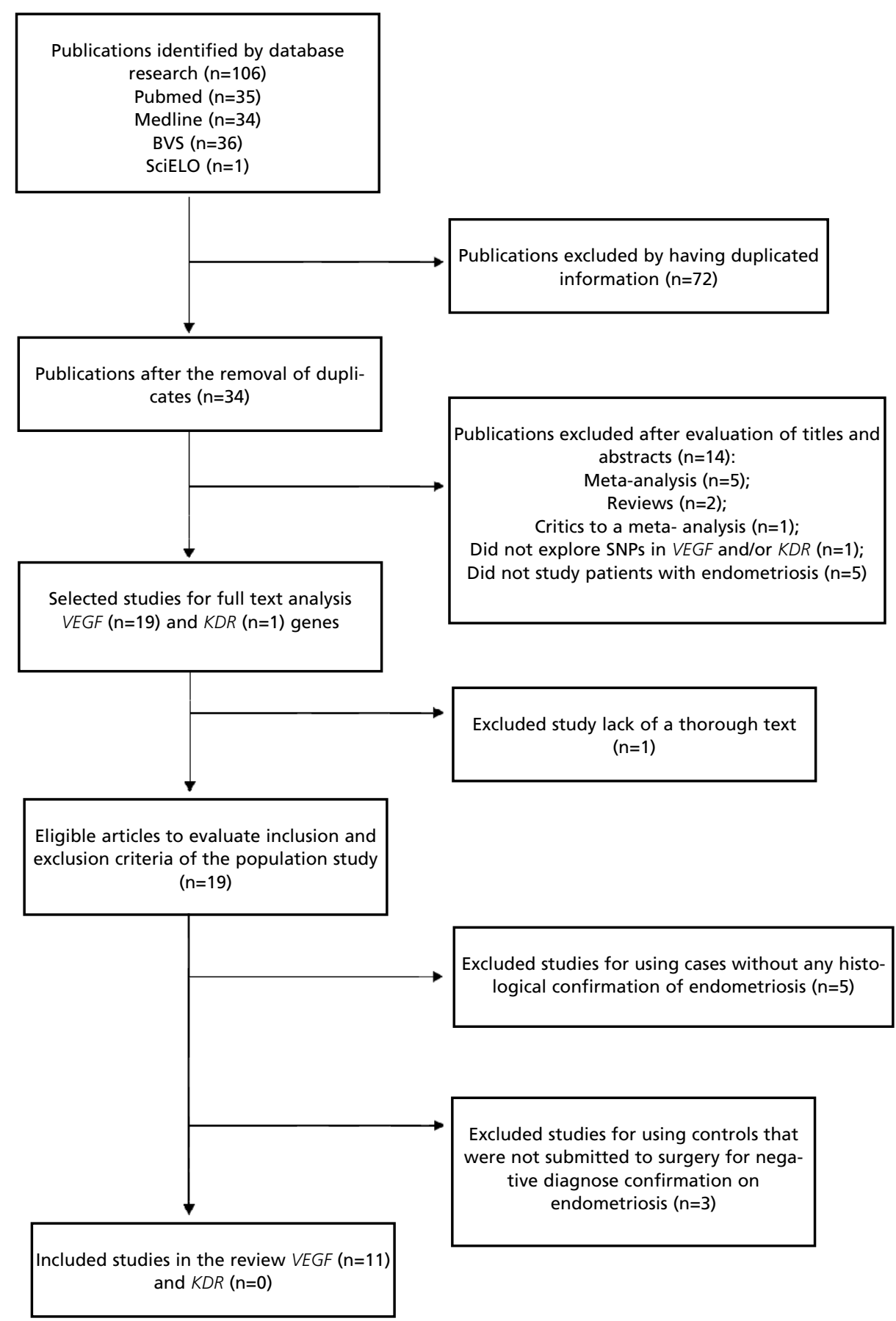


Table 1

\begin{tabular}{|c|c|c|c|c|c|}
\hline Reference, year & $\begin{array}{c}\text { Population } \\
\text { (N)* }\end{array}$ & Surgery** & $\begin{array}{l}\text { Endometriosis } \\
\text { staging**** } \\
\text { (N) }\end{array}$ & Exclusion criteria & $\begin{array}{c}\text { Quality Score } \\
\text { Strobe (\%) }\end{array}$ \\
\hline Kim et al.21 2005 & $\begin{array}{c}\text { Korean } \\
(215)\end{array}$ & $\begin{array}{l}\text { Laparoscopy or } \\
\text { laparotomy }\end{array}$ & $\begin{array}{l}\mathrm{III}=65 \\
\mathrm{IV}=150\end{array}$ & $\begin{array}{c}\text { Rheumatoid arthritis, GCA, } \\
\text { retinopathy diabetic, psoriasis, } \\
\text { Behcet's disease and endometriosis } \\
\text { I-II. }\end{array}$ & $19(86 \%)$ \\
\hline Gentilini et al.23 2008 & $\begin{array}{c}\text { Italian } \\
(203)\end{array}$ & Laparoscopy & $\begin{aligned} I-I I & =78 \\
I I I-I V & =125\end{aligned}$ & Pelvic inflammatory disease. & $18(82 \%)$ \\
\hline Kim et al.24 2008 & $\begin{array}{l}\text { Korean } \\
(105)\end{array}$ & Laparoscopy & $\begin{array}{c}I=20 ; I I=41 \\
I I I=11 ; I V=33\end{array}$ & $\begin{array}{l}\text { Amenorrhoea, previous surgery for } \\
\text { endometriosis or other pelvic } \\
\text { pathology for example myoma. }\end{array}$ & $12(55 \%)$ \\
\hline Cosin et al.26 2009 & $\begin{array}{l}\text { Spanish } \\
(186)\end{array}$ & Laparoscopy & $\begin{aligned} I-I I & =19 \\
I I I-I V & =167\end{aligned}$ & $\begin{array}{l}\text { Suspicion of endometriosis, but } \\
\text { without histopathological confir- } \\
\text { mation of the disease, } \\
\text { Menorrhagia, hypermenorrhagia, } \\
\text { who became pregnant or breast- } \\
\text { feeding for the past } 6 \text { months. }\end{array}$ & $20(91 \%)$ \\
\hline Liu et al.27 2009 & $\begin{array}{c}\text { Chinese } \\
(344)\end{array}$ & $\begin{array}{l}\text { Laparoscopy or } \\
\text { laparotomy }\end{array}$ & No information & No information & $19(86 \%)$ \\
\hline Altinkaya et al.31 2011 & $\begin{array}{l}\text { Turkish } \\
\text { (98) }\end{array}$ & Yes*** & $\begin{array}{c}\mathrm{I}=4 ; \mathrm{II}=18 \\
\mathrm{III}=41 ; \mathrm{IV}=35\end{array}$ & $\begin{array}{l}\text { Rheumatoid arthritis, GCA, diabetic } \\
\text { retinopathy, psoriasis or Behcet's } \\
\text { disease. }\end{array}$ & $17(77 \%)$ \\
\hline Emamifar et al.32 2012 & $\begin{array}{l}\text { Iranian } \\
(480)\end{array}$ & Yes & $I-I I$ & Endocrine therapy before surgery. & $15(68 \%)$ \\
\hline Rotman et al.33 2013 & $\begin{array}{c}\text { American } \\
\text { (24) }\end{array}$ & Laparoscopy & $\begin{array}{c}\mathrm{I}=3 ; \mathrm{II}=2 \\
\mathrm{III}=2 ; \mathrm{IV}=17\end{array}$ & No information & $13(59 \%)$ \\
\hline Perini et al.8 2014 & $\begin{array}{l}\text { Brazilian } \\
\quad(182)\end{array}$ & $\begin{array}{c}\text { Laparoscopy or } \\
\text { laparotomy }\end{array}$ & $\begin{array}{c}\mathrm{I}-\mathrm{II}=71 \\
\mathrm{III}-\mathrm{IV}=110 \\
\text { No information }=1\end{array}$ & History of cancer or Adenomyosis. & $21(96 \%)$ \\
\hline Henidi et al.36 2015 & $\begin{array}{l}\text { Tunisian } \\
(105)\end{array}$ & Laparoscopy & $\begin{array}{c}I=27 ; I I=36 \\
I I I=18 ; I V=24\end{array}$ & $\begin{array}{l}\text { Rheumatoid arthritis, GCA, diabetic } \\
\text { retinopathy, breast cancer, Behcet's } \\
\text { disease, leiomyoma, Adenomyosis, } \\
\text { myoma, carcinoma in situ of the } \\
\text { cervix or ovarian cancer. }\end{array}$ & $17(77 \%)$ \\
\hline $\begin{array}{l}\text { Szczepańska et al.37 } \\
2015\end{array}$ & $\begin{array}{l}\text { Polish } \\
(154)\end{array}$ & Laparoscopy & $\begin{array}{l}I=83 \\
I I=71\end{array}$ & $\begin{array}{l}\text { Mechanical distortion of the } \\
\text { endometrial cavity for fibroids, } \\
\text { tubal occlusion bilateral and factor } \\
\text { of male infertility. }\end{array}$ & $17(77 \%)$ \\
\hline
\end{tabular}

GCA $=$ giant cell arthritis: * $\mathrm{N}$ is the number of cases of endometriosis included in each article; ** Type of surgery for endometriosis diagnosis; $* *$ Yes = not specified the type of surgery performed; $* *$ Classification of endometriosis staging described by the American Society for Reproductive Medicine (1996, 1997), the American Society of Fertility $(1985,1997)$.

women who were submitted to surgery because of various problems such as appendicitis, carcinoma in situ of the cervix, dermoid cysts, parovarium cysts, serous cysts and mucinous tumors, dysmenorrhoea, pelvic pain, fibroma ovarian, dysfunctional bleeding uterine, hydrosalpinges, infertility and malformation of the uterine and normal pelvis. $8,21,23,27,31,37$ The exclusion criteria for the control group was one $(9.1 \%)$ study that did not inform any of the exclusion criteria. 33 The remaining $10(90.9 \%)$ considered almost the same exclusion criteria of the group with cases of endometriosis. $8,21,23,24,26,27,31,32,36,37$ 
In Table 3 shows investigated SNPs characteristics in the studies eligible for this review. 5 SNPs in $V E G F$ gene were studied being genotyped by PCRRFLP techniques $(81.8 \%)$ and PCR at real time (18.2\%). SNP rs699947 was evaluated in $2(18.2 \%)$ studies and the frequency of $V E G F-2578 \mathrm{~A}$ allele ranged between $19-40 \%$ and $26-34 \%$ in cases and controls, respectively. Liu et al. 27 observed a negative association with endometriosis, while Perini et al. 8 found no association to the disease (Table 4). SNP rs 833061 was evaluated in $8(72.7 \%)$ studies and the frequency of $V E G F-460 C$ allele ranged between $3-53 \%$ in cases and $1-51 \%$ in controls, however no study found an association of SNP with the development of the disease. $8,21,26,27,31,32,36,37$ Three $(27.3 \%)$ studies evaluated SNP rs 1570360 and the frequency of $V E G F-1154 \mathrm{~A}$ allele ranged between $16-28 \%$ and $16-27 \%$ in cases and controls, respectively (Table 3). However, Liu et al.27 and
Perini et al. 8 observed opposite effects, while Rotman et al. 33 found no association with the development of endometriosis (Table 4). SNP rs2010963 investigated $8(72.7 \%)$ studies and the frequency of $V E G F+405 C$ allele ranged between $33-56 \%$ in cases and $31-95 \%$ in controls (Table 3 ), although 4 studies (Table 4) found no association with endometriosis, $8,26,36,371$ study observed a positive association in the presence of $V E G F+405 G$ allele 31 and, contrary 3 studies verified a positive association in the presence of allele or $+405 \mathrm{C}$ genotype. $21,23,32$ Six studies $(54.5 \%)$ evaluated SNP rs3025039 and the frequency of $V E G F+936 T$ allele ranged between $13-25 \%$ and $10-17 \%$ in cases and controls, respectively (Table 3 ), however 4 studies found no association $8,23,27,37$ and 2 verified a positive association with endometriosis in the presence of $+936 T$ allele. 26,36

Table 2

\begin{tabular}{|c|c|c|c|c|c|c|}
\hline \multirow{3}{*}{$\begin{array}{l}\text { Reference, year } \\
\text { Kim et al.21 } 2005\end{array}$} & \multirow{3}{*}{$\begin{array}{l}\text { Control } \\
\text { (N) } \\
219\end{array}$} & \multirow{3}{*}{$\begin{array}{c}\begin{array}{c}\text { Source of } \\
\text { controls }\end{array} \\
\text { Hospital basis }\end{array}$} & \multirow{3}{*}{$\begin{array}{c}\begin{array}{c}\text { Surgery * } \\
\text { (N) }\end{array} \\
\begin{array}{c}\text { Laparoscopy or } \\
\text { laparotomy }\end{array}\end{array}$} & \multicolumn{2}{|c|}{ Reason for surgery } & \multirow[t]{2}{*}{ Exclusion criteria } \\
\hline & & & & \multicolumn{2}{|c|}{ Tubal ligation $(\mathrm{N})$ Others $* * *(\mathrm{~N})$} & \\
\hline & & & & No & Yes (219) & $\begin{array}{l}\text { Rheumatoid arthritis, GCA, diabetic } \\
\text { retinopathy, psoriasis, Behcet's disease, } \\
\text { endometriosis (I-II, leiomyoma, } \\
\text { Adenomyosis, carcinoma in situ of the } \\
\text { cervix or cancer of the ovary. }\end{array}$ \\
\hline Gentilini et al.23 2008 & 140 & Hospital basis & Laparoscopy & No & Yes (140) & Pelvic inflammatory disease. \\
\hline Kim et al.24 2008 & 101 & Hospital basis & Laparoscopy & No & $\begin{array}{c}\text { No } \\
\text { information }\end{array}$ & $\begin{array}{l}\text { Amenorrhoea, previous surgery for } \\
\text { endometriosis or other pelvic } \\
\text { pathology, as an example myoma. }\end{array}$ \\
\hline Cosin et al.26 2009 & 180 & Hospital basis & Laparoscopy & Yes $(180)$ & No & $\begin{array}{c}\text { Menorrhagia, hypermenorrhagia, who } \\
\text { became pregnant or breastfeeding in } \\
\text { the last } 6 \text { months }\end{array}$ \\
\hline Liu et al.27 2009 & 360 & $\begin{array}{l}\text { Based on } \\
\text { Population }\end{array}$ & $\begin{array}{c}\text { Laparoscopy or } \\
\text { laparotomy }\end{array}$ & No & $\begin{array}{c}\text { Yes (No } \\
\text { information) }\end{array}$ & Malignant disease or endometriosis. \\
\hline Altinkaya et al.31 2011 & 94 & Hospital Basis & Laparoscopy & No & Yes (94) & $\begin{array}{l}\text { Rheumatoid arthritis, GCA, diabetic } \\
\text { retinopathy, psoriasis and Behçet's dis- } \\
\text { ease. }\end{array}$ \\
\hline Emamifar et al.32 2012 & 600 & Hospital Basis & Yes** & Yes $(600)$ & No & $\begin{array}{l}\text { Endocrine therapy before surgery, } \\
\text { endometriosis, inflammatory disease } \\
\text { and myoma. }\end{array}$ \\
\hline
\end{tabular}


Table 2

Description of the inclusion and exclusion criteria of the control group, established by eligible studies for this review.

\begin{tabular}{|c|c|c|c|c|c|c|}
\hline \multirow[t]{2}{*}{ Reference, year } & \multirow{2}{*}{$\begin{array}{l}\text { Control } \\
\text { (N) }\end{array}$} & \multirow{2}{*}{$\begin{array}{l}\text { Source of } \\
\text { controls }\end{array}$} & \multirow{2}{*}{$\begin{array}{l}\text { Surgery * } \\
\text { (N) }\end{array}$} & \multicolumn{2}{|c|}{ Reason for surgery } & \multirow[t]{2}{*}{ Exclusion criteria } \\
\hline & & & & Tubal ligation $(\mathrm{N})$ & Others***(N) & \\
\hline Rotman et al.33 2013 & 18 & Hospital Basis & Laparoscopy & $\begin{array}{c}\text { No } \\
\text { information }\end{array}$ & $\begin{array}{c}\text { No } \\
\text { information }\end{array}$ & No information \\
\hline Perini et al.8 2014 & 112 & Hospital Basis & $\begin{array}{c}\text { Laparoscopy or } \\
\text { laparotomy }\end{array}$ & Yes (51) & Yes (61) & History of cancer or Adenomyosis \\
\hline Henidi et al.36 2015 & 150 & Hospital Basis & Laparoscopy & $\begin{array}{c}\text { No } \\
\text { information }\end{array}$ & $\begin{array}{c}\text { No } \\
\text { information }\end{array}$ & $\begin{array}{l}\text { Rheumatoid arthritis, GCA, diabetic } \\
\text { retinopathy, breast cancer, Behcet's dis- } \\
\text { ease, leiomyoma, Adenomyosis, myoma, } \\
\text { carcinoma in situ of the cervix or ovarian } \\
\text { cancer. }\end{array}$ \\
\hline $\begin{array}{l}\text { Szczepańska et al.37 } \\
2015\end{array}$ & 135 & Hospital Basis & Laparoscopy & No & Yes (135) & $\begin{array}{l}\text { Signs of inflammation, past or present, } \\
\text { pelvic abnormalities and bilateral tubal } \\
\text { occlusion. }\end{array}$ \\
\hline
\end{tabular}

$\overline{\mathrm{GCA}}=$ giant cell arthritis; * Type of surgery performed; ** Yes = not specified the type of surgery performed; $* *$ Other reasons for conducting surgical procedure include appendicitis, carcinoma in situ of the cervix, dermoid cysts, parovarium cysts, serous cysts and mucinous tumors, dysmenorrhoea, pelvic pain, ovarian fibroma, dysfunctional uterine bleeding, hydrosalpinx, infertility and malformation of the uterine and normal pelvis.

Table 3

Polymorphisms characteristics of VEGF gene analyzed in eligible studies for this review.

\begin{tabular}{|c|c|c|c|c|c|}
\hline \multirow[t]{2}{*}{ rs } & \multirow{2}{*}{$\begin{array}{l}\text { Site of } \\
\text { the gene }\end{array}$} & \multirow[t]{2}{*}{ Genotyping technique } & \multirow[t]{2}{*}{ Reference, year } & \multicolumn{2}{|c|}{ Variant allele frequency } \\
\hline & & & & Case & Control \\
\hline & & & & & \\
\hline \multirow[t]{3}{*}{ rs699947 } & $\mathrm{RP}$ & TaqMan- real time PCR & Perini et al.8 2014 & 40 & 34 \\
\hline & & PCR-RFLP & Liu et al.27 2009 & 19 & 26 \\
\hline & & & & & \\
\hline \multirow[t]{8}{*}{ rs833061 } & $\mathrm{RP}$ & TaqMan- real time PCR & Perini et al.8 2014 & 43 & 40 \\
\hline & & PCR-RFLP & Kim et al.21 2005 & 28 & 26 \\
\hline & & PCR-RFLP & Cosin et al.26 2009 & 47 & 49 \\
\hline & & PCR-RFLP & Liu et al.27 2009 & 23 & 21 \\
\hline & & PCR-RFLP & Altinkaya et al.31 2011 & 3 & 1 \\
\hline & & PCR-RFLP & Emamifar et al.32 2012 & 33 & 31 \\
\hline & & PCR-RFLP & Henidi et al.36 2015 & 40 & 42 \\
\hline & & real time PCR & Szczepańska et al.37 2015 & 53 & 51 \\
\hline
\end{tabular}

$\mathrm{RP}=$ promoter region; 5'UTR = 5' untranslated region ; 3'UTR = 3' untranslated region; PCR-RFLP = polymerase chain reaction - restriction fragment length polymorphism. 
Table 3

concluded

Polymorphisms characteristics of VEGF gene analyzed in eligible studies for this review.

Site of Genotyping technique

Reference, year

Variant allele frequency

the gene

Case

Case Control

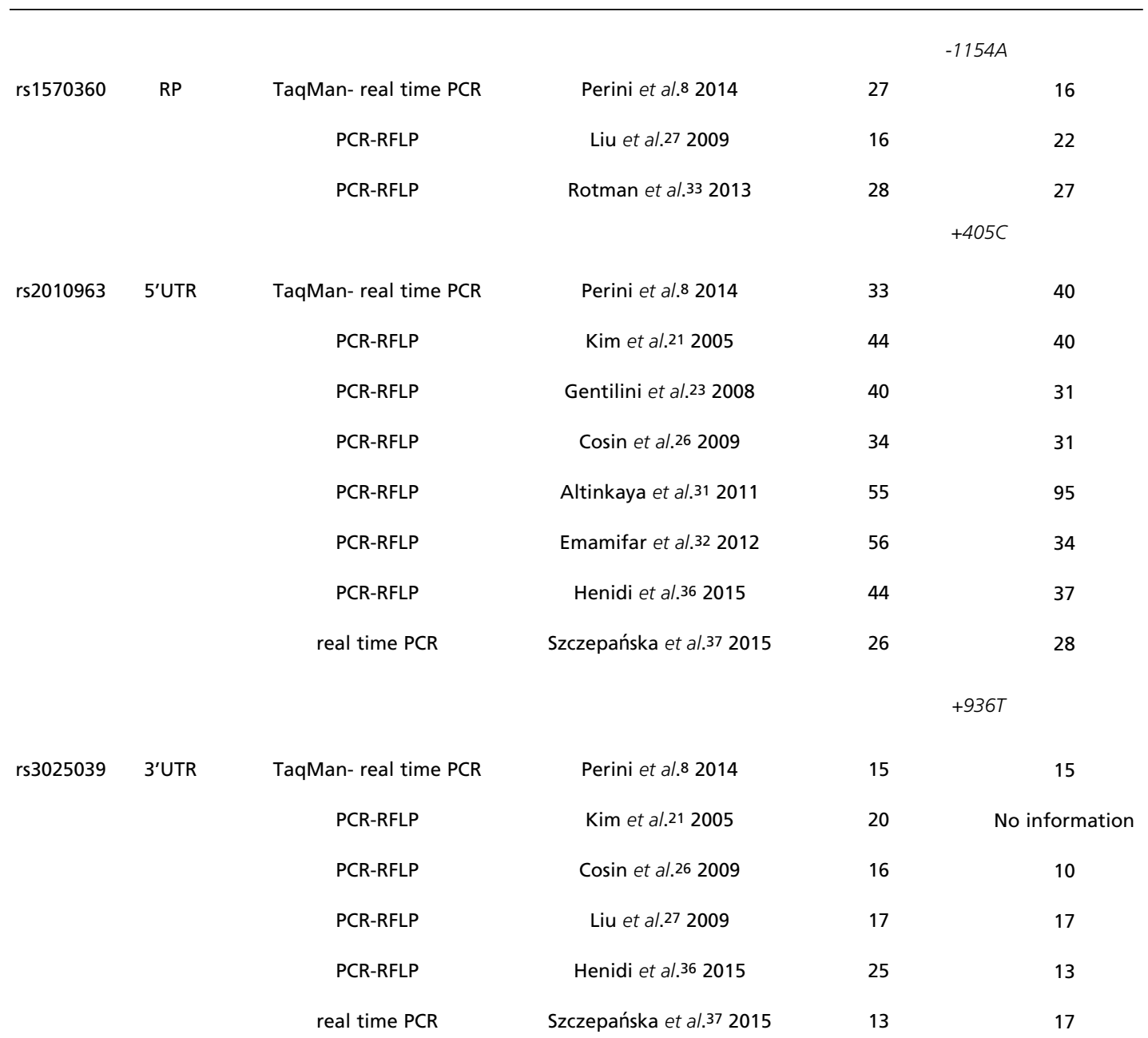

$\overline{\mathrm{RP}}=$ promoter region; 5'UTR = 5' untranslated region ; 3'UTR = 3' untranslated region; PCR-RFLP = polymerase chain reaction - restriction fragment length polymorphism. 
Table 4

Description of the results concerning the magnitude of association of the polymorphism in VEGF gene with endometriosis, according to studies eligible for this review.

\begin{tabular}{|c|c|c|c|c|}
\hline Gene/SNP & Reference, year & Association & $\begin{array}{l}\text { Allele or } \\
\text { genotype } \\
\text { associated }\end{array}$ & OR (Cl95\%) \\
\hline \multirow{2}{*}{$\begin{array}{l}\text { VEGF }-2578 C>A \\
\text { (rs699947) }\end{array}$} & Liu et al.27 2009* & Yes & $A A$ & $0,34(0,17-0,70)$ \\
\hline & Perini et al.8 2014* & No & - & - \\
\hline $\begin{array}{l}V E G F-460 T>C \\
(\mathrm{rs} 833061)\end{array}$ & $\begin{array}{c}\text { Perini et al.8 2014*, Kim et al.21 2005, } \\
\text { Cosín et al.26 2009*, Liu et al.27 2009*, } \\
\text { Altinkaya et al.31 2011, Emamifar et al.32 } \\
\text { 2011, Henidi et al.36 } 2015 \text { and } \\
\text { Szczepańska et al.37 } 2015\end{array}$ & No & - & - \\
\hline \multirow{3}{*}{$\begin{array}{l}\text { VEGF -1154G>A } \\
(\text { rs1570360) }\end{array}$} & Perini et al.8 2014* & Yes & $A A$ & $6,17(1,37-27,8)$ \\
\hline & Liu et al.27 2009* & Yes & $A A$ & $0,26(0,11-0,67)$ \\
\hline & Rotman et al.33 2013 & No & - & - \\
\hline \multirow{5}{*}{$\begin{array}{l}V E G F+405 G>C \\
(\mathrm{rs} 2010963)\end{array}$} & Kim et al.21 2005 & Yes & $\mathrm{CC}$ & $1,99(1,20-3,28)$ \\
\hline & Gentilini et al.23 2008 & Yes & C & $1,80(1,2-2,8)$ \\
\hline & Altinkaya et al.31 2011 & Yes & G & $14,8(7,38-29,7)$ \\
\hline & Emamifar et al.32 2012 & Yes & $\mathrm{CC}$ & $3,78(2,74-5,21)$ \\
\hline & $\begin{array}{c}\text { Perini et al.8 2014*, Cosín et al.26 2009*, } \\
\text { Henidi et al.36 } 2015 \text { and Szczepańska et } \\
\text { al.37 } 2015\end{array}$ & No & - & - \\
\hline \multirow{3}{*}{$\begin{array}{l}V E G F+936 C>T \\
(\mathrm{rs} 3025039)\end{array}$} & Cosin et al.26 2009 * & Yes & $\mathrm{T}$ & $1,75(1,12-2,74)$ \\
\hline & Henidi et al.36 2015 & Yes & $\mathrm{T}$ & $2,19(1,39-3,46)$ \\
\hline & $\begin{array}{c}\text { Perini et al.8 2014*, Kim et al.24 2008, Liu } \\
\text { et al.27 2009* and Szczepańska et al.37 } \\
2015\end{array}$ & No & - & - \\
\hline
\end{tabular}

$(-)=$ not applicable; $\mathrm{OR}=$ odds ratio; $\mathrm{Cl}=$ confidence interval; *Authors that used statistical methods to calculate the adjusted OR.

\section{Discussion}

This review provides a detailed description of the studies that used a case-control design study to investigate the magnitude of association of the SNPs in $V E G F$ and/or $K D R$ genes susceptibility in the deve-lopment of endometriosis. The angiogenesis, through $V E G F-K D R$ signals, is an important event in the development of the disease, 11,12 since endometriosis lesions are characterized by a dense vascularization and requires blood supply suitable for survival.11 Furthermore, an increased expression of $V E G F$ and $V E G F R-2$ in samples of women with endometriosis was observed when compared to its control. 12

The expression of $V E G F$ and $K D R$ genes as well as the activity of these proteins may be modified by the presence of polymorphisms in coding regions and non-coding genes.16-18 SNPs that occur in promoter regions, 5'-UTR and 3'-UTR, affect potential regulatory elements, are sensitive to hypoxia and contribute to high variability of production in VEGF tissues. $18,39,40$ rs699947, rs833061 and rs 1570360 SNPs present in the promoter region of $V E G F$ gene, 
present higher activity of transcription and are associated to high levels of protein. ${ }^{41}$ rs2010963 SNP located in region 5'-UTR of VEGF gene affects the efficiency of understanding and is related to the production of $V E G F$ from the mononucleated cells of the peripheral blood. ${ }^{42}$ So, rs3025039 SNP in region 3'-UTR of $V E G F$ gene influences the concentration of $V E G F$ plasmatic stock. 15 rs2305948 and rs 1870377 SNPs located in the exons of $K D R$ gene decrease the efficiency of $V E G F$ binding to $K D R .18$ The possible effect of rs7667298 SNP located in region 5'-UTR of $K D R$ gene is unclear. However, this SNP is associated to rs2071559 SNP (KDR$604 T>C$ ) located in the promoter region. The presence of $-604 \mathrm{C}$ allele reduces the transcriptional activity of $K D R .18$ rs 1531289 and rs7692791 SNPs located in introns of $K D R$ gene were not yet studied in relation to the functional effects.

$V E G F-K D R$ role in endometriosis physiopathology as well as the influence of SNPs to modulate the levels and activity of these proteins justify the high number of studies that attempted to describe the magnitude of SNPs association of $V E G F$ and $K D R$ genes susceptibility in endometriosis developing.8,17,19-37 In 2013, Li et al.,43 conducted a meta-analysis study involving 14 studies which investigated the magnitude of association of 5 SNPs in the VEGF gene (rs699947, rs833061, rs1570360, rs2010963 and rs3025039) in the susceptibility on endometriosis. The increased risk of endometriosis developing was observed in the presence of $V E G F+936 C>T$ SNP, while $V E G F$ $2578 C>A$ and $-1154 G>A$ SNPs were protective factors for the development of the disease. Thus, $V E G F-460 T>C$ and $+405 G>C$ SNPs were not associated to the development of endometriosis. ${ }^{43}$ For $K D R$, only one case-control design study evaluated the magnitude of association among five SNPs (rs1531289, rs2305948, rs1870377, rs7692791 and rs7667298) and the development of endometriosis in Chinese women, noticing a negative association in the presence of $1192 T$ allele (rs2305948).17 However, this study was excluded from this review because included controls performed only an ultrasound to diagnose negative for endometriosis and this method of imaging does not exclude the presence of pelvic endometriosis. ${ }^{44,45}$ Moreover, until the present moment there are no data in literatures that assess the combined form of SNPs in $V E G F$ and $K D R$ genes and the development of endometriosis.

The controversial results observed in the casecontrol studies can be explained by the sample size, by methodological differences in each study design, mainly, by the eligible control type, by the difference in SNPs frequency in different populations and by the use of the measured of association, the unadjusted odds ratio (OR) used to evaluate the magnitude of association of SNPs in the VEGF and KDR genes in the development of endometriosis. The stratification techniques and multiple regression are two statistical methods which can be used to exclude potential confounding variables and consequently produce the adjusted OR. ${ }^{46,47}$ Among the 11 studies included in this review, only $3(27.3 \%)$ used the adjusted OR (Table 4) to evaluate the magnitude of association of SNPs in VEGF gene and the development of endometriosis. 8,26,27 The manner in which the variables are measured may insert a bias and distort the estimated measurement of the effect. 48 The confounding variables occur when part of the association found is the result of the presence of a third variable that is related to the disease and the exposure of interest result in a change of the estimated risk. 49

The analytical observational epidemiological studies of the case-control type are applied to evaluate exposures among similar groups, which present (cases) or not (controls) to the disease. 50 They are widely used in studies on rare diseases or in long period of induction and regular expositions, 51 such as in the case of endometriosis. In addition, casecontrol studies tend to contribute in locating important findings and efficient in terms of relatively short time with little financial resource. 48 However, casecontrol studies tend to be more susceptible to biases than any other analytical epidemiological designs and how individuals are recruited for the study can distort the estimated measurement of the effect.51 The definition of the case group is a critical point in a case-control study, criteria for diagnosis and eligibility and two fundamental aspects for the selection of the subject. The aim is to ensure that all the true cases have equal probability of joining the group, and that no false case is selected, thus, it may distort the estimated measurement of the association in direction to a null hypothesis. ${ }^{52}$ In 19 published studies which analyzed $V E G F$ and $K D R$ polymorphisms in susceptibility to the development of endometriosis, it was observed that the cases of endometriosis had surgical diagnosis. $8,17,20-34,36,37$ In spite of the available images of the method presented a good accuracy in the endometriosis diagnosis, according to a consensus of the European Society of Human Reproduction and Embryology (ESHRE) and the American Society for Reproductive Medicine (ASRM), the gold standard to diagnose endometriosis is the videolaparoscopy with direct inspection of the pelvic cavity and visu- 
alization of the implants, as well as the histopathological confirmation of the disease. 53,54 Thus, 11 articles were included in this review using the "gold standard" to select the cases (surgical and histopathological confirmation), considered to be a good diagnostic criteria and eligibility, ensuring that all 2096 women included were true cases of endometriosis. $8,21,23,24,26,27,31,32,33,36,37$

The selection of the control group requires special care and perhaps is the main challenge to guarantee the validity of the study, considering the complexity of the investigated disease (endometriosis). The control group of studies included in this review was formed by women who could have other diseases, including gynecological disorders associated to the development of endometriosis, along with the process of angiogenesis and/or polymorphisms in $V E G F$ gene. 17,39,55,56 Approximately $82 \%(\mathrm{n}=9)$ of the studies included in this review used the control group that presented other gynecological diseases or had no information about the reason for a surgical procedure performed by a gynecologist (laparoscopy and/or laparotomy), being able to provide low risk estimates, considering these diseases and/or the reason why a woman underwent surgery may be associated to the exposure under investigated (SNPs of $V E G F$ gene). It is fundamental that the control group is directly determined by the definition and selection of the case group sampled by the same source. 57 Among the 11 studies included in this review, about $91 \%(n=10)$ used controls of hospital basis (Table 2). $8,21,23,24,26,31-33,36,37$ It has been described in the literature that about $11 \%$ of the women with endometriosis have no symptoms of the disease. 6,7 In addition, the average time between the onset of the symptoms and the diagnosis of endometriosis is extensively long, ranging between 7 to 12 years. 58 We emphasize that 4 articles were excluded from this review,22,25,29,30 because they did not use adequate control to evaluate the magnitude of SNPs association to $V E G F$ gene and the development of endometriosis. In a study conducted by Zhao et al. 25 the controls were women who reported not having endometriosis and only $27 \%$ had a negative diagnosis of endometriosis by laparoscopy or hysterectomy. Toktam et al.,30 used control of hospital basis, however it was not informed whether the women had undergone surgical procedure, they only reported that they had gynecological problems. Lamp et al. ${ }^{29}$ used healthy fertile women (with at least 2 children), without clinical suspicion of endometriosis and without performing a surgical procedure to exclude the presence of the disease. Ikuhashi et al.22 used umbilical cord as control material obtained from newborn females.

The main limitations of the case-control studies are: the lack of validity due to the selected bias; the recruitment of controls are not representative to the population at risk; errors on the measurements associated to the function of different biases between cases and controls and the confounding variables that affect a causal association. ${ }^{50}$ The differences in the allelic frequency pattern can be observed in the studies with ethnic groups, as well as environmental factors contributing to different phenotypic responses. ${ }^{59}$ Furthermore, it should be taken into account the sample size to avoid making type I errors, stating that the risk factor is associated to the disease, but, in fact, it is not; or type II errors, stating that the risk factor is not associated with the disease, but, in fact, it is. 50 Among the 11 articles included in this review, only $3(27 \%)$ of them informed the calculated sample used in the study.21,23,26 Moreover, we emphasize the limited number of cases and controls included in Rotman et al. 33 study ( 24 cases and 18 controls) and Attar et al.28 (52 cases and 60 controls) and the latter was excluded from this review because they used cases without histological confirmation of endometriosis.

According to Zondervan et al.,57 the choice of the ideal control group for the study on genetic basis of endometriosis is free of diseases, whereas is submitted to surgery for tubal ligation. Among the 11 studies included in this review, approximately $27 \%(n=3)$ used women who underwent tubal ligation in the control group, $8,26,32$ and only $2(18 \%)$ studies were formed exclusively by a control group of women who underwent the procedure of tubal ligation. 26,32 Corroborating with these findings, we also suggest that the ideal control group perform case-control studies, which evaluates the genetic profile of women with endometriosis and should be informed by women submitted to tubal ligation, because it is possible to make a direct inspection of the pelvic cavity and exclude the presence of endometriosis lesions.

This review had the intention to describe and discuss the inclusion/exclusion criteria used to define the cases group with endometriosis and especially the controls group, in order to verify methodological differences that could contribute to the discrepancies in the results found in the literature. The analytical observational studies on case-control, when they are carefully designed can provide relevant information to identify risk factors, especially in cases of endometriosis, which is a complex disease and multifactorial. The epidemiological 
analyzes which explore the molecular profile of women with endometriosis may contribute to the etiologic investigation and build instruments for the actions and interventions in the field of the public health.

In conclusion, we suggest broader studies with correct methodological design involving different populations as well as a combined analysis of SNPs in $V E G F$ and/or $K D R$ genes are still necessary in virtue of the fundamental role of these factors in the endometriosis development. We suggest a selection of a control group from a hospital basis, without history of infertility and gynecological disorders, such as the case of women undergoing tubal ligation

\section{References}

1. Giudice LC. Clinical practice. Endometriosis. N Engl J Med. 2010; 362: 2389-98.

2. Giudice LC, kao LC. Endometriosis. Lancet. 2004; 364 (9447): 1789-99.

3. Buck Louis GM, Hediger ML, Peterson CM, Croughan M, Sundaram R, Stanford J, Chen Z, Fujimoto VY, Varner MW, Trumble A, Giudice LC; ENDO Study Working Group. Incidence of endometriosis by study population and diagnostic method: the ENDO study. Fertil Steril. 2011; 96 (2) $360-5$.

4. Viganò $P$, Parazzini F, Somigliana E, Vercellini $P$. Endometriosis: epidemiology and aetiological factors. Best Pract Res Clin Obstet Gynaecol. 2004; 18: 177-200.

5. Inceboz U. Endometriosis after menopause. Womens Health (Lond Engl). 2015; 11 (5): 711-5.

6. Fauconnier A, Staraci S, Roman Chh, Panel P, Descamps P. Comparison of patient- and physician-based descriptions of symptoms of endometriosis: a qualitative study. Human Reprod. 2013; 28: 2686-94.

7. Moradi M, Parker M, Sneddon A, Lopez V, Ellwood D Impact of endometriosis on women's lives: a qualitative study. BMC Womens Health. 2014; 14: 123.

8. Perini JA, Cardoso JV, Berardo PT, Vianna-Jorge R, Nasciutti LE, Bellodi-Privato M, Machado DE, Abrão MS. Role of vascular endothelial growth factor polymorphisms $(-2578 \mathrm{C}>\mathrm{A}, \quad-460 \quad \mathrm{~T}>\mathrm{C}, \quad-1154 \mathrm{G}>\mathrm{A}, \quad+405 \mathrm{G}>\mathrm{C}$ and $+936 \mathrm{C}>\mathrm{T}$ ) in endometriosis: a case-control study with Brazilians. BMC Womens Health. 2014; 14:117.

9. De Graaff AA, D'hooghe TM, Dunselman GA, Dirksen CD, Hummelshoj L, WERF EndoCost Consortium, et al. The significant effect of endometriosis on physical, mental and social wellbeing: results from an international crosssectional survey. Hum Reprod. 2013; 28:2677-85.

10. Sampson JA. Peritoneal endometriosis due to the menstrual dissemination of endometrial tissue into the peritoneal cavity. Am J Obstet Gynecol. 1927; 14: 422-69.

11. Rocha ALL, Reis FM, Taylor RN. Angiogenisis and Endometriosis. Obstet Gynecol Int. 2013; 2013:859619.

12. Machado DE, Abrão MS, Berardo PT, Takiya CM, Nasciutti procedures corresponds to the appropriate control type to evaluate the magnitude of SNPs association of $V E G F$ and/or $K D R$ genes in the endometriosis development.

\section{Acknowledgements}

To the Fundação de Amparo à Pesquisa do Estado do Rio de Janeiro (FAPERJ);

To the Conselho Nacional de Desenvolvimento Científico e Tecnológico (CNPq);

To the Fundação do Câncer (Projeto Oncobiologia).
LE. Vascular density and distribution of vascular endothelial growth factor (VEGF) and its receptor VEGFR-2 (Flk1) are significantly higher in patients with deeply infiltrating endometriosis affecting the rectum. Fertil Steril 2008; 90: 148-55.

13. Vincenti V, Cassano C, Rocchi M, Persico G. Assignment of the vascular endothelial growth factor gene to human chromosome 6p21.3. Circulation. 1996; 93: 1493-5.

14. Lu D, Kussie P, Pytowski B, Persaud K, Bohlen P, Witte L, Zhu Z. Identification of the residues in the extracellular region of KDR important for interaction with vascular endothelial growth factor and neutralizing anti-KDR antibodies. J Biol Chem. 2000; 275: 14321-30.

15. Renner W, Kotschan S, Hoffmann C, Obermayer-Pietsch B, Pilger E. A common $936 \mathrm{C} / \mathrm{T}$ mutation in the gene for vascular endothelial growth factor is associated with vascular endothelial growth factor plasma levels. J Vasc Res. 2000; 37: 443-8.

16. Jain L, Vargo CA, Danesi R, Sissung TM, Price DK, Venzon D, Venitz J, Figg WD. The role of vascular endothelial growth factor SNPs as predictive and prognostic markers for major solid tumors. Mol Cancer Ther. 2009; 8: 2496-508.

17. Kang S, Shi YY, Li Y, Wang N, Lu YC, Zhou RM, Zhao $\mathrm{XW}$. Association between genetic variants of the VEGFR-2 gene and the risk of developing endometriosis in Northern Chinese Women. Gynecol Obstet Invest 2013; 76:32-7.

18. Wang Y, Zheng Y, Zhang W, Yu H, Lou K, Zhang Y, Qin Q, Zhao B, Yang Y, Hui R. Polymorphisms of KDR gene are associated with coronary heart disease. J Am Coll Cardiol. 2007; 50: 760-7.

19. Hsieh YY, Chang CC, Tsai FI, Yeh LS, Lin CC, Peng CT. T allele for VEGF gene-460 polymorphism at the 5 '-untranslated region: association with a higher susceptibility to endometriosis. J Reprod Med. 2004; 49: 468-72.

20. Bhanoori M, Arvind Babu K, Pavankumar Reddy NG, Lakshmi Rao K, Zondervan K, Deenadayal M, Kennedy S, Shivaji S. The vascular endothelial growth factor (VEGF) $+405 \mathrm{G}>\mathrm{C}$ 5'-untranslated region polymorphism and increased risk of endometriosis in South Indian women: a case control study. Hum Reprod. 2005; 20: 1844-9. 
21. Kim SH, Choi YM, Choung SH, Jun JK, Kim JG, Moon SY. Vascular endothelial growth factor gene $+405 \mathrm{C} / \mathrm{G}$ polymorphism is associated with susceptibility to advanced stage endometriosis. Hum Reprod. 2005; 20: 2904-8.

22. Ikuhashi Y, Yoshida S, Kennedy S, Zondervan K, Takemura N, Deguchi M, Ohara N, Maruo T. Vascular endothelial growth factor $+936 \mathrm{C} / \mathrm{T}$ polymorphism is associated with an increased risk of endometriosis in a Japanese population. Acta Obstet Gynecol Scand. 2007; 86: 1352-8.

23. Gentilini D, Somigliana E, Vigano P, Vignali M, Busacca M, Di Blasio AM. The vascular endothelial growth factor $+405 \mathrm{G} \& \mathrm{gt}$; C polymorphism in endometriosis. Hum Reprod. 2008; 23: 211-5.

24. Kim JG, Kim JY, Jee BC, Suh CS, Kim SH, Choi YM. Association between endometriosis and polymorphisms in endostatin and vascular endothelial growth factor and their serum levels in Korean women. Fertil Steril. 2008; 89: 2435 .

25. Zhao ZZ, Nyholt DR, Thomas S, Treloar SA, Montgomery GW. Polymorphisms in the vascular endothelial growth factor gene and the risk of familial endometriosis. Mol Hum Reprod. 2008; 14: 531-8

26. Cosín R, Gilabert-Estellés J, Ramón LA, España F, Gilaber J, Romeu A, Estellés A. Vascular endothelial growth factor polymorphisms $(-460 \mathrm{C} / \mathrm{T},+405 \mathrm{G} / \mathrm{C}$, and $936 \mathrm{C} / \mathrm{T})$ and endometriosis: their influence on vascular endothelial growth factor expression. Fertil Steril. 2009; 92: 1214-2.

27. Liu Q, Li Y, Zhao J, Sun DL, Duan YN, Wang N, Zhou RM, Kang S.. Association of polymorphisms -1154G/A and $2578 \mathrm{C} / \mathrm{A}$ in the vascular endothelial growth factor gene with decreased risk of endometriosis in Chinese women. Hum Reprod. 2009; 24: 2660-6.

28. Attar R, Agachan B, Kuran SB, Toptas B, Eraltan IY, Attar E, Isbir T. Genetic variants of vascular endothelial growth factor and risk for the development of endometriosis. In Vivo. 2010; 24: 297-301

29. Lamp M, Saare M, Laisk T, Karro H, Kadastik U, Metspalu A, Peters M, Salumets A. Genetic variations in vascular endothelial growth factor but not in angiotensin Iconverting enzyme genes are associated with endometriosis in Estonian women. Eur J Obstet Gynecol Reprod Biol. 2010; 153: 85-9.

30. Toktam M, Kioomars SN, Kourosh K, Adel S, Behrokh MM, Mohhamad Mehdi A, Hamid Reza KK. Association of vascular endothelial growth factor (VEGF) $+405 \mathrm{G}>\mathrm{C}$ polymorphism with endometriosis in an Iranian population. $\mathrm{J}$ Reprod Infertil. 2010; 11: 33-7.

31. Altinkaya SO, Ugur M, Ceylaner G, Ozat M, Gungor T, Ceylaner S. Vascular endothelial growth factor $+405 \mathrm{C} / \mathrm{G}$ polymorphism is highly associated with an increased risk of endometriosis in Turkish women. Arch Gynecol Obstet 2011; 283: 267-72.

32. Emamifar B, Salehi Z, Mehrafza M, Mashayekhi F. The vascular endothelial growth factor (VEGF) polymorphisms and the risk of endometriosis in northern Iran. Gynecol Endocrinol 2012; 28: 447-50.

33. Rotman C, Fischel L, Cortez G, Greiss H, Rana N, Rinehart J, Coulam CB. A search to identify genetic risk factors for endometriosis. Am J Reprod Immunol. 2013; 69: 92-5

34. Saliminejad K, Memariani T, Ardekani AM, Kamali K,
Edalatkhah H, Pahlevanzadeh Z, Khorram Khorshid HR. Association study of the TNF- $\alpha-1031 \mathrm{~T} / \mathrm{C}$ and VEGF $+450 \mathrm{G} / \mathrm{C}$ polymorphisms with susceptibility to endometriosis. Gynecol Endocrinol. 2013; 29: 974-7.

35. Ahmed MM, Khaled ARRN, Hisham SH, Wael TE, Waleed SAE. Vascular endothelial growth factor gene polymorphism as a risk factor of endometriosis. Evidence Based Women's Health J. 2014; 4 (2): 92-5.

36. Henidi B, Kaabachi W, Naouali A, Kaabachi S, Zhioua A, Haj Sassi F, Hamzaoui K. Vascular endothelial growth factor $(-460 \mathrm{C} / \mathrm{T},+405 \mathrm{G} / \mathrm{C}$, and $+936 \mathrm{C} / \mathrm{T})$ polymorphisms and endometriosis risk in Tunisian population. Syst Biol Reprod Med. 2015; 61: 238-44.

37. Szczepańska M, Mostowska A, Wirstlein P, Skrzypczak J, Jagodziłski PP. Involvement of vascular endothelial growth factor $-460 \mathrm{C} / \mathrm{T},+405 \mathrm{G} / \mathrm{C}$ and $+936 \mathrm{C} / \mathrm{T}$ polymorphisms in the development of endometriosis. Biomed Rep. 2015; 3: 220-4.

38. Von EE. Strengthening the Reporting of Observational Studies in Epidemiology (STROBE) statement: guidelines for reporting observational studies. Brit Med J. 2007; 355 (7624): 806-8.

39. Awata T, Inoue K, Kurihara S, Ohkubo T, Watanabe M, Inukai $\mathrm{K}$, Inoue I, Katayama S. A common polymorphism in the 5'-untranslated region of the VEGF gene is associated with diabetic retinopathy in type 2 diabetes. Diabetes. 2002; 51: 1635-9

40. Steffensen KD,Waldstrøm M, Brandslund I, Jakobsen A. The relationship of VEGF polymorphisms with serum VEGF levels and progression-free survival in patients with epithelial ovarian cancer. Gynecol Oncol. 2010; 117: 109.

41. Brogan IJ, Khan N, Isaac K, Hutchinson JA, Pravica V, Hutchinson IV. Novel polymorphisms in the promoter and 5 ' UTR regions of the human vascular endothelial growth factor gene. Hum Immunol. 1999; 60: 1245-9.

42. Watson CJ, Webb NJ, Bottomley MJ, Brenchley PE. Identification of polymorphisms within the vascular endothelial growth factor (VEGF) gene: correlation with variation in VEGF protein production. Cytokine. 2000; 12: 1232-5.

43. Li YZ, Wang LJ, Li X, Li SL, Wang JL, Wu ZH, Gong L, Zhang XD. Vascular endothelial growth factor gene polymorphisms contribute to the risk of endometriosis: an updated systematic review and meta-analysis of 14 casecontrol studies. Genet Mol Res. 2013; 12: 1035-44

44. Menakaya U, Reid S, Infante F, Condous G. Systematic evaluation of women with suspected endometriosis using a 5-domain sonographically based approach. J Ultrasound Med. 2015; 34 (6): 937-47.

45. Nisenblat V1, Bossuyt PM, Farquhar C, Johnson N, Hull ML. Imaging modalities for the non-invasive diagnosis of endometriosis. Cochrane Database Syst Rev. 2016 Feb 26; 2: CD009591.

46. Fuchs SC, Paim BS. Revisão Sistemática de Estudos Observacionais com Metanálise. Rev HCPA 2010; 30: 294301 .

47. Camey SA, Torman VB, Hirakata VN, Cortes RX, Vigo A Bias of using odds ratio estimates in multinomial logistic regressions to estimate relative risk or prevalence ratio and alternatives. Cad Saúde Pública. 2014; 30: 21-9. 
48. Rego MAV. Aspectos históricos dos estudos caso-controle. Cad Saúde Pública. 2001; 17: 1017-24.

49. Luiz Rr, Struchiner CJ. Inferência causal em epidemiologia: o modelo de respostas potenciais [online]. Rio de Janeiro: Editora FIOCRUZ; 2002. 112 p.

50. Schulz KF, Grimes DA. Case-control studies: research in reverse. Lancet. 2002; 359: 431-4.

51. Rêgo MAV. Estudos caso-controle: uma breve revisão. Gazeta Médica da Bahia. 2010; 79: 101-10.

52. Lasky T, Stolley PD. Selection of cases and controls. Epidemiol Rev. 1994;16:6-17.

53. ASRM - American Society for Reproductive Medicine. Revised American Fertility Society Classification Of Endometriosis: 1996. Fertil Steril. 1997.

54. ESHRE Guideline for the Diagnosis and Treatment of Endometriosis. http://guidelines endometriosis org/ 2008.

55. Boiardi L, Casali B, Nicoli D, Farnetti E, Chen Q, Macchioni P, Catanoso MG, Pulsatelli L, Meliconi R, Salvarani C. Vascular endotelial growth factor gene polymorphisms in giant cell arteritis. J Rheumatol. 2003; 30: 2160-4.

Received on April 4, 2016

Final version presented on August 2, 2016

Approved on August 9, 2016
56. Salvarani C, Boiardi L, Casali B, Olivieri I, Cantini F, Salvi F, Malatesta R, La Corte R, Triolo G, Ferrante A, Filippini D, Paolazzi G, Sarzi-Puttini P, Nicoli D, Farnetti E, Chen Q, Pulsatelli L. Vascular endotelial growth factor gene polymorphisms in Behçet's disease. J Rheumatol. 2004; 31 : $1785-9$

57. Zondervan KT, Cardon LR, Kennedy SH. What makes a good case-control study? Design issues for complex traits such as endometriosis. Hum Reprod. 2002; 17: 1415-23.

58. Arruda MS, Petta CA, Abrão MS, Benetti-Pinto CL. Time elapsed from onset of symptoms to diagnosis of endometriosis in a cohort study of Brazilian women. Hum Reprod. 2003; 18: 756-9.

59. Kennedy S: Genetics of endometriosis: a review of the positional cloning approaches. Semin Reprod Med. 2003, 21: 111-8. 